\title{
The role of $s t j$ fimbrial operon in the intestinal persistence of Salmonella Typhimurium in mice
}

\author{
Nefise Akkoç ${ }^{1}$, Banu Özden ${ }^{1}$, Begüm G. TAN ${ }^{2} \&$ Mustafa AkÇElik ${ }^{1 *}$ \\ ${ }^{1}$ Department of Biology, Faculty of Science, Ankara University, Do Gol Street, Tandoğan 06100 Ankara, Turkey; e-mail: \\ akcelik@science.ankara.edu.tr \\ ${ }^{2}$ Faculty of Medicine, Hacettepe University, Sihhıye 06100 Ankara, Turkey
}

\begin{abstract}
Salmonella Typhimurium contains 13 operons coding for fimbriae with unique binding specificities to host epithelial surfaces. stj operon is only detected in $S$. Typhimurium genome suggesting that Stj fimbria may effect serovarspecific virulence characteristics. In this study, the role of stj fimbrial operon in the long-term persistence of $S$. Typhimurium was identified by competitive infection experiment in genetically resistant mouse (CBA) model system. Knock-out mutation of $\operatorname{stj} A$ (major subunit of the Stj fimbria) gene reduced recovery of $S$. Typhimurium from fecal samples and its colonization to spleen, cecum and mesenteric lymph nodes over a 34-day time period $(p<0.05)$. This data indicate that stj fimbrial operon has a role in long-term intestinal persistence of $S$. Typhimurium in CBA mice.
\end{abstract}

Key words: $S$. Typhimurium; stj; fimbria; intestinal persistence.

Abbreviations: BCIP, 5-bromo-4-chloro-3-indolyl-phosphate; CFU, colony forming unit; LB, Luria-Bertani; MLN, mesenteric lymph nodes; PBS, phosphate buffered saline.

\section{Introduction}

The genus Salmonella comprises two species, Salmonella enterica and Salmonella bongori. S. enterica includes seven subspecies of clinical importance for humans causing million of cases of food borne disease in the world every year (Linam \& Gerber 2007; Grassl \& Finlay 2008). S. enterica serotype Typhimurium ( $S$. Typhimurium) is a motile pathogen that has adapted to invading and surviving for long periods in its human and mouse hosts (Tükel et al. 2005, 2006; Weening et al. 2005). $S$. Typhimurium related human gastroenteritis is initiated by the colonization of intestinal epithelium followed by invasion of $\mathrm{M}$ cells and enterocytes (Ledeboer et al. 2006). Fimbriae play a critical role in virulence of Salmonella by allowing these bacteria to interact with intestinal epithelium (Edwards et al. 2000; Raffatellu et al. 2006).

$S$. Typhimurium genome contains 13 fimbrial operons of the chaperone/usher class: agf (csg), fim, lpf, pef, $b c f$, stb, ste, std, stf, sth, sti, saf and stj (Weening et al. 2005; Tükel et al. 2007; Chessa et al. 2008b). Expression of these operons is regulated by environmental signals, such as temperature, iron, $\mathrm{pH}$, osmolarity, aliphatic amino acids, oxygen levels and carbon source (Nicholson \& Low 2000). Only two type I fimbriae, encoded by the fim operon (Stolpe et al. 1994) and thin aggregative fimbriae encoded by agf (csg) gene cluster
(Romling et al. 1998) are highly expressed in vitro. The lack of the in vitro expression of the other fimbrial operons including stj has prevented identification of their functions. stj fimbrial operon was identified only by sequence analysis of $S$. Typhimurium genome (Porwollik et al. 2002).

In this study, we present the evidence that Stj fimbria enhances $S$. Typhimurium survival in the mouse model system.

\section{Material and methods}

Bacterial strains and media

$S$. Typhimurium LT2 is a standard laboratory strain which was first isolated by Lilleengen (1948). S. Typhimurium IR715 (Stojilkovic et al. 1995) is a spontaneous nalidixic acid-resistant virulent variant of ATCC 14028. Strain AJB715 is a phoN mutant derivative of IR715 and has been previously described (Kingsley et al. 2004). Escherichia coli

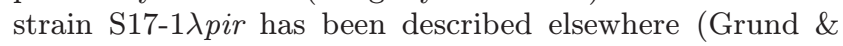
Weber 1988). Bacteria were cultured aerobically at $37^{\circ} \mathrm{C}$ in Luria-Bertani (LB) broth. Antibiotics were used at the following concentrations: kanamycin, $100 \mu \mathrm{g} / \mathrm{mL}$; and nalidixic acid, $50 \mu \mathrm{g} / \mathrm{mL}$.

\section{DNA manipulations}

The $s t j A$ gene upstream and downstream fragments were amplified to construct $S$. Typhimurium $s t j$ mutant by using the primers:

5'GCAGATCTGCGGAAGTGATTTCACGG3',

\footnotetext{
* Corresponding author
} 


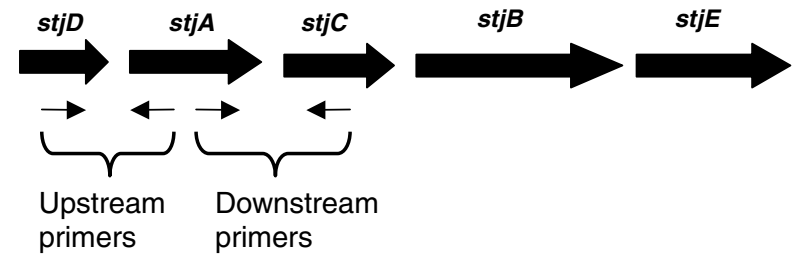

Fig. 1. PCR amplified stjA gene upstream and downstream fragments (lanes; 1: $1 \mathrm{~kb}$ DNA ladder; 2: stjA upstream fragment, $650 \mathrm{bp}$; and 3: stjA downstream fragment, $1041 \mathrm{bp}$ ).

\section{5'CGGTCGACCCAAATGACATGTAATGCGCGGGTC GGG3' and \\ 5'CGGTCGACCTCCAGCATTCACATGGAATATTCA ACACC3', \\ 5'GCTCTAGATCCAGTTTCACACCATTGTCGTC3'.}

Amplified PCR fragments were cloned into the vector PCR 2.1 (TOPO TA Cloning Kit, Invitrogen). The two fragments flanking the stj operon were then cloned into the suicide vector pGP704 (Kinder et al. 1993) digested with $X B a \mathrm{I}$ and $B g l \mathrm{II}$. A kanamycin resistance gene cassette from plasmid pUC4-KIXX (Barany 1985) was cloned into SalI restriction site where the two stj $\mathrm{A}$ fragments connected on the plasmid pGP704. The resulting plasmid was introduced into $E$. coli $\mathrm{S} 17-1 \lambda$ pir and then conjugated into IR715. The inserts of the resulting plasmid were sequenced by RefGen (METU Teknokent, Ankara). Conjugants were selected on LB agar plates containing kanamycin $(100 \mu \mathrm{g} / \mathrm{mL})$ and nalidixic acid $(50 \mu \mathrm{g} / \mathrm{mL})$. The donor strain E. coli $\mathrm{S} 17-$ $1 \lambda$ pir cannot grow on this medium because of lack of diaminopimelate. Southern blot analysis was performed by using an internal stjA fragment as a DNA probe to confirm the insertion of pGP704 into $S$. Typhimurium IR715 chromosome by homologous recombination. This recombinant was termed as MA44.

\section{Competitive infection experiments}

Four resistant CBA mice were inoculated orally with $2 \times 10^{8}$ colony forming unit (CFU) of a 1:1 mixture of AJB715 and MA44 in a volume of $0.1 \mathrm{~mL}$ phosphate buffered saline (PBS). Fecal and organ samples - cecum, ileum and mesenteric lymph nodes (MLN) - were homogenized and serially diluted for determination of $\mathrm{CFU}$ and input ratio. Double plating was performed on LB agar plates containing kanamycin $(100 \mu \mathrm{g} / \mathrm{mL})$, nalidixic acid $(50 \mu \mathrm{g} / \mathrm{mL})$ and 30 $\mu \mathrm{g} / \mathrm{mL}$ of 5 -bromo-4-chloro-3-indolyl-phosphate (BCIP) in order to distinguish phoN $^{-}$(alkaline phosphatase) AJB715 and $\mathrm{phoN}^{+}$MA44. Data obtained from competitive infection experiments were normalized by dividing the output ratio (CFU mutant/CFU wild-type) by the input ratio (CFU mutant/CFU wild-type). All data were converted logarithmically prior to the calculation of geometric means and statistical analysis. Statistical significance was determined by using Student's $t$ test. $\mathrm{P}$ values of $<0.05$ were considered as statistically significant.

\section{Results and discussion}

To determine if $s t j$ operon conferred persistence to $S$. Typhimurium in genetically resistant mice (CBA) we constructed a stj mutant, termed as MA44, by chromosomal insertion of suicide plasmid pGP704. To this end, upstream and downstream DNA regions of the

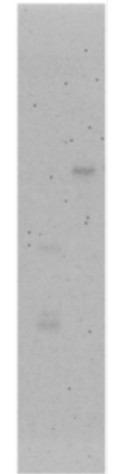

Fig. 2. Southern blot of genomic DNA isolated from $S$. Typhimurium strains IR715 (wild type, lane 1) and MA44 (stjA mutant, lane 2), detected with DNA probe specific for $s t j A$ gene.

main subunit gene (stjA) of stj operon were amplified (Fig. 1) and cloned into pGP704. A kanamycin resistance gene cassette from plasmid pUC4 was inserted between upstream and downstream fragments of stjA gene on pGP704 in SalI restriction site and resulting

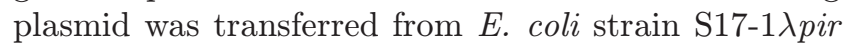
(Simon et al. 1983) into $S$. Typhimurium IR715 strain by conjugation. stj operon knockout mutants contained kanamycin gene cassette insertion via homologous recombination of $s t j \mathrm{~A}$ gene fragments in which common on the suicide plasmid pGP704 and $S$. Typhimurium IR715 chromosome were selected as conjugants which were $\mathrm{dap}^{+}$and kanamycin resistant. Insertion of the suicide plasmid containing kanamycin gene cassette between stjA gene fragments was confirmed by Southern blotting (Fig. 2) by using genomic DNA of $S$. Typhimurium and DNA specific probes for major subunit gene $(s t j \mathrm{~A})$ of $s t j$ operon.

To investigate the role of $s t j$ fimbrial operon in intestinal persistence, competitive inhibition experiments were done with a group of four CBA mice. An equal mixture of the stj mutant (MA44) and the strain $S$. Typhimurium AJB715 $\left(\sim 10^{6} \mathrm{CFU} / \mathrm{mL}\right)$ was used to inoculate the CBA mice group intragastrically. $S$. Typhimurium strain AJB715 carries a mutation in phoN gene, a gene encoding nonspecific acid phosphatase and controls the blue color phenotype of cells on agar plates containing the chromogenic substrate BCIP (Kier et al. 1977). Inactivation of $p h o \mathrm{~N}$ gene has been shown not to effect intestinal colonization and virulence of $S$. Typhimurium for mice (Kingsley et al. 2004). Growth on LB agar plates supplemented with BCIP thus provided an easy means to distinguish the stj mutants.

Mice fecal pellets were collected at 3, 7, 9, 14, 17, $21,25,28,30$ and 34 days after infection. Numbers of competing strain AJB715 (phoN ${ }^{-}$, white colonies) and the $s t j$ fimbrial mutant MA44 $\left(\mathrm{phoN}^{+}\right.$, blue colonies) were determined by spreading serial ten-fold dilutions of fecal homogenates on LB agar plates supplemented with BCIP and appropriate antibiotics. Over 34-day time period of experiment, stj mutant MA44 was recovered at significantly lower numbers $(\mathrm{p}<0.05)$ than 
Table 1. Competitive infection results in mice fecal samples. ${ }^{a}$

\begin{tabular}{|c|c|c|c|c|c|}
\hline Days & $\begin{array}{c}\text { AJB715 } \\
(\mathrm{CFU} / \mathrm{mL})\end{array}$ & $\begin{array}{c}\text { MA44 } \\
(\mathrm{CFU} / \mathrm{mL})\end{array}$ & $\begin{array}{l}\text { AJB715/MA44 } \\
(\mathrm{CFU} / \mathrm{mL})\end{array}$ & $\begin{array}{l}\text { Normalized to } \\
\text { input ratio }\end{array}$ & $\log$ \\
\hline \multicolumn{6}{|l|}{ Day 3} \\
\hline mouse 1 & 1 & 610 & 0.001639 & 0.0020708 & -2.68387219 \\
\hline mouse 2 & 8000 & 145000 & 0.055172 & 0.0696915 & -1.15682037 \\
\hline mouse 3 & 6800 & 900 & 7.555556 & 9.5438596 & 0.97972404 \\
\hline mouse 4 & 1 & 20 & 0.05 & 0.0631579 & -1.19957235 \\
\hline \multicolumn{6}{|l|}{ Day 7} \\
\hline mouse 1 & 10 & 590 & 0.016949 & 0.0214095 & -1.66939437 \\
\hline mouse 2 & 25200000 & $2.6 \mathrm{e}-07$ & 0.965517 & 1.2196007 & 0.08621767 \\
\hline mouse 3 & 46000 & 23000 & 2 & 2.5263158 & 0.40248764 \\
\hline mouse 4 & 1 & 1 & 1 & 1.2631579 & 0.10145764 \\
\hline \multicolumn{6}{|l|}{ Day 9} \\
\hline mouse 1 & 200 & 500 & 0.4 & 0.5052632 & -0.29648237 \\
\hline mouse 2 & 9800000 & 8200000 & 1.195122 & 1.5096277 & 0.17886986 \\
\hline mouse 3 & 8000 & 145000 & 0.055172 & 0.0696915 & -1.15682037 \\
\hline mouse 4 & 1 & 1 & 1 & 1.2631579 & 0.10145764 \\
\hline \multicolumn{6}{|l|}{ Day 14} \\
\hline mouse 1 & 1 & 110000 & $9.09 \mathrm{e}-06$ & $1.148 \mathrm{e}-05$ & -4.93993504 \\
\hline mouse 2 & 2370000 & 1590000 & 1.490566 & 1.8828203 & 0.27480886 \\
\hline mouse 3 & 360000 & 2450000 & 0.146939 & 0.1856069 & -0.73140594 \\
\hline mouse 4 & 10 & 500 & 0.02 & 0.0252632 & -1.59751236 \\
\hline \multicolumn{6}{|l|}{ Day 17} \\
\hline mouse 1 & 550000 & 80000 & 6.875 & 8.6842105 & 0.93873034 \\
\hline mouse 2 & 4300000 & 1600000 & 2.6875 & 3.3947368 & 0.53080611 \\
\hline mouse 3 & 1500000 & 600000 & 2.5 & 3.1578947 & 0.49939765 \\
\hline mouse 4 & 40000 & 315000 & 0.126984 & 0.160401 & -0.79479292 \\
\hline \multicolumn{6}{|l|}{ Day 21} \\
\hline mouse 1 & 290000 & 1330000 & 0.218045 & 0.2754254 & -0.559996 \\
\hline mouse 2 & 26700000 & 9100000 & 2.934066 & 3.7061885 & 0.56892751 \\
\hline mouse 3 & 37000 & 56000 & 0.660714 & 0.8345865 & -0.07852866 \\
\hline mouse 4 & 380000 & 530000 & 0.716981 & 0.9056604 & -0.04303463 \\
\hline \multicolumn{6}{|l|}{ Day 25} \\
\hline mouse 1 & 1130000 & 50000 & 22.6 & 22.6 & 1.45556608 \\
\hline mouse 2 & 19900000 & 4900000 & 4.061224 & 4.061224 & 0.71011464 \\
\hline mouse 3 & 10 & 20 & 0.5 & 0.5 & -0.19957235 \\
\hline mouse 4 & 328000 & 63000 & 5.206349 & 5.206349 & 0.81799094 \\
\hline \multicolumn{6}{|l|}{ Day 28} \\
\hline mouse 1 & 10000 & 2000 & 5 & 6.3157895 & 0.80042765 \\
\hline mouse 2 & 18800000 & 4700000 & 4 & 5.0526316 & 0.70351763 \\
\hline mouse 3 & 2010000 & 208000 & 9.663462 & 12.206478 & 1.08659036 \\
\hline mouse 4 & 5400000 & 200000 & 27 & 34.105263 & 1.5328214 \\
\hline \multicolumn{6}{|l|}{ Day 30} \\
\hline mouse 1 & 1900 & 1200 & 1.583333 & 2 & 0.30103 \\
\hline mouse 2 & 42000000 & 9600000 & 4.375 & 5.5263158 & 0.7424357 \\
\hline mouse 3 & 4000 & 700 & 5.714286 & 7.2180451 & 0.85841959 \\
\hline mouse 4 & 1900 & 100 & 19 & 24 & 1.38021124 \\
\hline \multicolumn{6}{|l|}{ Day 34} \\
\hline mouse 1 & 70 & 10 & 7 & 8.8421053 & 0.94655568 \\
\hline mouse 2 & 26100000 & 2600000 & 10.03846 & 12.680162 & 1.1031248 \\
\hline mouse 3 & 40 & 1 & 40 & 50.526316 & 1.70351763 \\
\hline mouse 4 & 1 & 1 & 40 & 50.526316 & 1.70351763 \\
\hline \multicolumn{6}{|c|}{ Statistical analysis } \\
\hline Day & Mean & Standa & ion & Standard error & $P$ value \\
\hline 3 & -1.01513522 & & & 0.753781 & 0.1133548 \\
\hline 7 & -0.26980785 & & & 0.472177 & 0.2942346 \\
\hline 9 & -0.29324381 & & & 0.306112 & 0.1875372 \\
\hline 14 & -1.74851112 & & & 1.130498 & 0.0864517 \\
\hline 17 & 0.2935353 & & & 0.376321 & 0.2325156 \\
\hline 21 & -0.02815795 & & & 0.231323 & 0.0435964 \\
\hline 25 & 0.69602482 & & & 0.340841 & 0.0435964 \\
\hline 28 & 1.03083926 & & & 0.186038 & 0.0007291 \\
\hline 30 & 0.82052413 & & & 0.221859 & 0.0050538 \\
\hline 34 & 1.36417894 & & & 0.198507 & 0.000234 \\
\hline
\end{tabular}

${ }^{a}$ Data given as $\mathrm{CFU} / \mathrm{mL}$, multiply by 5 to get $\mathrm{CFU} /$ organ. 
(a)

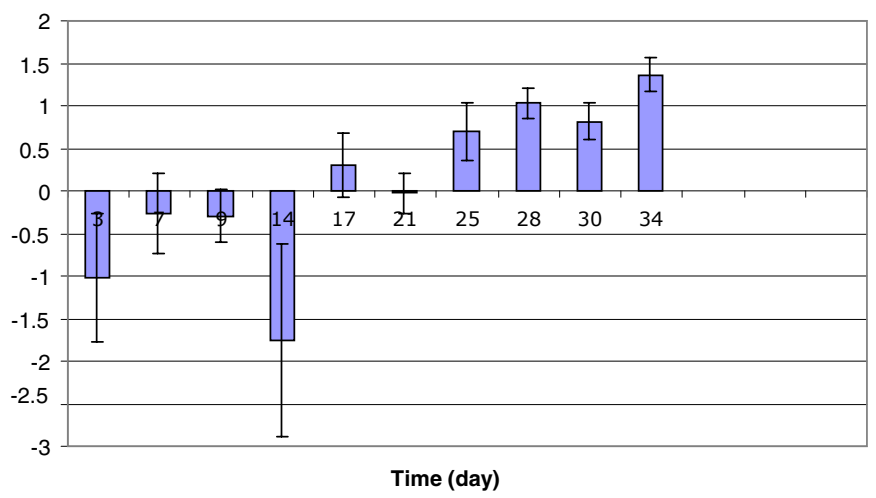

(b)

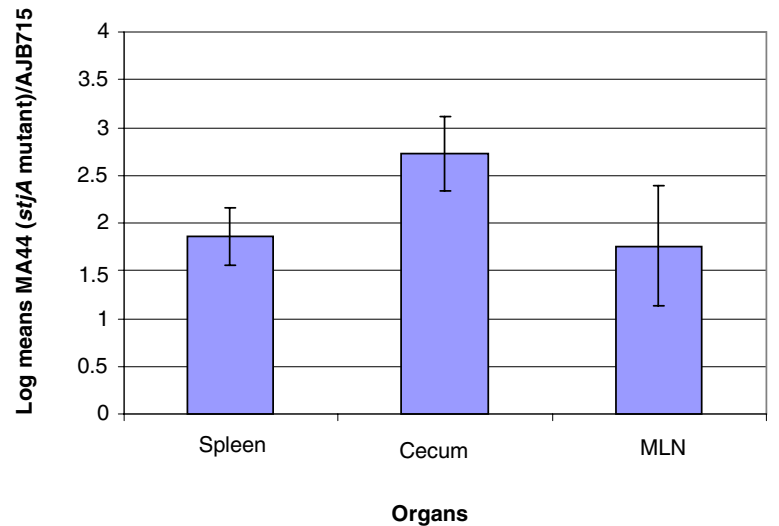

Fig. 3. Competitive infection experiment results from CBA mice feces (a) and organs (b). Mice were infected with a mixture of equal amounts of AJB715 and stj mutant (MA44). Ratios of MA44/AJB715 recovered from feces over a 34-day time period and spleen, cecum and mesenteric lymph nodes (MLN) of mice at 34 days after infection were plotted as log means.

Table 2. Competitive infection results in mice organ samples. ${ }^{a}$

\begin{tabular}{|c|c|c|c|c|c|}
\hline Organs & $\begin{array}{c}\text { AJB715 } \\
(\mathrm{CFU} / \mathrm{mL})\end{array}$ & $\begin{array}{c}\text { MA44 } \\
(\mathrm{CFU} / \mathrm{mL})\end{array}$ & $\begin{array}{l}\text { AJB715/MA44 } \\
\quad(\mathrm{CFU} / \mathrm{mL})\end{array}$ & $\begin{array}{l}\text { Normalized to } \\
\text { input ratio }\end{array}$ & $\log$ \\
\hline \multicolumn{6}{|l|}{ Spleen } \\
\hline mouse 1 & 520 & 1 & 520 & 656.8421053 & 2.81746098 \\
\hline mouse 2 & 45 & 1 & 45 & 56.84210526 & 1.75467015 \\
\hline mouse 3 & 110 & 5 & 22 & 27.78947368 & 1.44388032 \\
\hline mouse 4 & 20 & 1 & 20 & 25.26315789 & 1.40248764 \\
\hline \multicolumn{6}{|l|}{ Cecum } \\
\hline mouse 1 & 108 & 1 & 108 & 136.4210526 & 2.1348814 \\
\hline mouse 2 & 3500 & 4 & 875 & 1105.263158 & 3.04346569 \\
\hline mouse 3 & 7800 & 120 & 65 & 82.10526316 & 1.914371 \\
\hline mouse 4 & 5000 & 1 & 5000 & 6315.789474 & 3.80042765 \\
\hline \multicolumn{6}{|l|}{ MLN } \\
\hline mouse 1 & 1 & 1 & 1 & 1.263157895 & 0.10145764 \\
\hline mouse 2 & 890 & 1 & 890 & 1124.210526 & 3.05084765 \\
\hline mouse 3 & 115 & 12 & 9.583333333 & 12.10526316 & 1.08297424 \\
\hline mouse 4 & 500 & 1 & 500 & 631.5789474 & 2.80042765 \\
\hline \multicolumn{6}{|c|}{ Statistical analysis } \\
\hline Organs & Mean & \multicolumn{2}{|c|}{ Standard deviation } & Standard error & $P$ value \\
\hline Spleen & 1.85462477 & \multicolumn{2}{|c|}{0.66085386} & 0.296347024 & 0.000682347 \\
\hline Cecum & 2.72328643 & \multicolumn{2}{|c|}{0.86858364} & 0.38949939 & 0.000382134 \\
\hline MLN & 1.75892679 & \multicolumn{2}{|c|}{1.40924322} & 0.631947633 & 0.023381781 \\
\hline
\end{tabular}

${ }^{a}$ Data given as $\mathrm{CFU} / \mathrm{mL}$, multiply by 5 to get $\mathrm{CFU} /$ organ.

the competing strain AJB715 (Fig. 3a, Table 1). At the entire peripheral site samples (spleen, cecum and MLN), the mutant was less able to colonize than the wild-type strain AJB715 ( $p<0.05)$ (Fig. 3b, Table 2). These results indicate that $s t j$ fimbrial operon has a role in the colonization and long-term intestinal persistence of $S$. Typhimurium in mice.

Bacteria are capable to expressing a variety of surface structures, such as fimbriae in response to diverse environmental conditions. Fimbriae are thin, proteinaceous, polymeric non-motile structures which mediate adhesion of the cell to host tissue or to bacteria of same or different species. These interactions are committed steps leading to subsequent colonization of epithelial surfaces, entry into host cells or bacterial conjugation
(Duguid et al. 1966; Cogan et al. 2004; Ledeboer et al. 2006; Chessa et al. 2008a). Many of gene clusters corresponding to fimbrial system are present in genomes of enteric bacteria. Genetic analyses have shown that a series of horizontal transfer and deletion events have resulted in a high distribution pattern of fimbrial operons observed for the Salmonella serovars (Baumler et al. 1997; Humphries et al. 2001; Cogan et al. 2004; Forest et al. 2007). The in vivo expression of many fimbrial structures, such as Bcf, Fim, Lpf, Pef, Stb, Stc, Std, Stf and Sti has been demonstrated from $S$. Typhimurium infected bovine ileal loops; most of them were not, however, expressed in vitro (Romling et al. 1998; Humphries et al. 2003, 2005; Chessa et al. 2008b).

Stj fimbrial operon was identified by DNA sequence 
analysis of $S$. Typhimurium LT2 genome (McClelland et al. 2001; Porwollik et al. 2002). There is not any information about the role of Stj fimbria in virulence or persistence of $S$. Typhimurium in the host system. This is the first report showing that the $s t j$ fimbrial operon affects colonization and long-term persistence of $S$. Typhimurium in mouse model systems. Additional experiments, such as cloning and in vitro expression of Stj fimbria in homologous and heterologous hosts and determination of regulation characteristics of $s t j$ operon in $S$. Typhimurium are needed to strengthen this prediction.

\section{Acknowledgements}

This research was supported by The Scientific and Technological Research Council of Turkey (TUBİTAK), under the project entitled "Salmonella enterica serotip Typhimurium'dastj Fimbriyal Operonunun Regülasyonunun ve Patojenitede Oynadığı Rolün Tanımlanması" (107T459).

\section{References}

Barany F. 1985. Single-stranded hexameric linkers: a system for in-phase insertion mutagenesis and protein engineering. Gene 37: 111-123.

Baumler A.J., Tsolis R.M. \& Heffron F. 1997. Fimbrial adhesins of S. Typhimurium. Adv. Exp. Med. Biol. 412: 149-158.

Chessa D., Dorsey C.W., Winter M.G. \& Baumler A.J. 2008a. Binding specificity of Salmonella plasmid-encoded fimbriae assessed by glycomics. J. Biol. Chem. 28: 8118-8124.

Chessa D., Winter M.G., Nuccio S.P., Tükel C. \& Baumler A.J. 2008b. RossE repress std fimbrial expression in Salmonella enterica serotype Typhimurium. Mol. Microbiol. 68: 573587.

Cogan T. A., Jørgensen F., Lappin-Scott H. M., Benson C. E., Woodward M. J. \& Humphrey T. J. 2004. Flagella and curli fimbriae are important for the growth of Salmonella enterica serovars in hen eggs. Microbiology 150: 1063-1071.

Duguid J.P., Anderson E.S. \& Campbell I. 1966. Fimbriae and adhesive properties in Salmonellae. J. Pathol. Bacteriol. 92: $107-137$.

Edwards R.A., Schifferli D.M. \& Maloy S.R. 2000. A role for Salmonella fimbriae in intraperitoneal infections. Proc. Natl. Acad. Sci. USA 97: 1258-1262.

Forest C., Faucher S.P., Poirier K., Houle S., Dozois C.M. \& Daigle F. 2007. Contribution of the stg fimbrial operon of Salmonella enterica Serovar Typhi during interaction with human cells. Infect. Immun. 75: 5264-5271.

Grassl G.A. \& Finlay R.B. 2008. Pathogenesis of enteric Salmonella infections. Curr. Opin. Gastroenterol. 24: 22-26.

Grund S. \& Weber A. 1988. A new type of fimbriae on Salmonella typhimurium. Zentralbl. Veterinarmed. B35: 779-782.

Humphries A.D., DeRidder S. \& Baumler A.J. 2005. Salmonella enterica serotype Typhimurium fimbrial proteins serve as antigens during infection of mice. Infect. Immun. 73: 53295338 .

Humphries A.D., Raffatellu M., Winter S., Weening E.H., Kingsley R.A., Droleskey R., Zhang S., Figueiredo J., Khare S., Nunes J., Adams L.G., Tsolis R.M. \& Baumler A.J. 2003. The use of flow cytometry to detect expression of subunits encoded by 11 Salmonella enterica serotype Typhimurium fimbrial operons. Mol. Microbiol. 48: 1357-1376.

Humphries A.D.,Townsend S.M., Kingsley R.A., Nicholson T.L., Tsolis R.M. \& Baumler A.J. 2001. Role of fimbriae as antigens and intestinal colonization factors of Salmonella serovars. FEMS Microbiol. Lett. 201: 121-126.

Kier L.D., Weppelman R.M. \& Ames B.N. 1977. Regulation of two phosphatases and a cyclic phosphodiesterase of Salmonella typhimurium. J. Bacteriol. 130: 420-428.
Kinder S.A., Badger J.L., Bryant G.O., Pepe J.C. \& Miller V.L. 1993. Cloning of the YenI restriction endonuclease and methyltransferase from Yersinia enterocolitica serotype O8 and construction of a transformable R-M + mutant. Gene 136: $271-275$.

Kingsley R.A., Abi Ghanem D., Puebla-Osorio N., Keestra A.M., Berghman L. \& Baumler A.J. 2004. Fibronectin binding to the Salmonella enterica Serotype Typhimurium ShdA autotransporter protein is inhibited by a monoclonal antibody recognizing the A3 repeat. J. Bacteriol. 186: 4931-4939.

Ledeboer N.A., Frye J.G., McClelland M. \& Jones B.D. 2006. Salmonella enterica serovar Typhimurium requires the Lpf, Pef, and Tafi fimbriae for biofilm formation on HEp-2 tissue culture cells andchicken intestinal epithelium. Infect. Immun. 74: 3156-3169.

Lilleengen K. 1948. Typing of Salmonella typhimurium by means of bacteriophage. Acta. Pathol. Microbiol. Scand. 77 (Suppl.): 2-125.

Linam W.M. \& Gerber M.A. 2007. Changing epidemiology and prevention of Salmonella infections. Pediatr. Infect. Dis. J. 26: $747-748$.

McClelland M., Sanderson K.E., Spieth J., Clifton S.W., Latreille P., Courtney L., Porwollik S., Ali J., Dante M., Du F., Hou S., Layman D., Leonard S., Nguyen C., Scott K., Holmes A., Grewal N., Mulvaney E., Ryan E., Sun H., Florea L., Miller W., Stoneking T., Nhan M., Waterston R. \& Wilson R.K. 2001. Complete genome sequence of Salmonella enterica serovar Typhimurium LT2. Nature 413: 852-856.

Nicholson B. \& Low D. 2000. DNA methylation-dependent regulation of Pef expression in Salmonella typhimurium. Mol. Microbiol. 35: 728-742.

Porwollik S., Wong R.M. \& McClelland M. 2002. Evolutionary genomics of Salmonella: gene acquisitions revealed by microarray analysis. Proc. Natl. Acad. Sci. USA 99: 8956-8961.

Raffatellu M., Chessa D., Wilson R.P., Tükel Ç., Akçelik M. \& Baumler A.J. 2006. Capsule-mediated immune evasion: a new hypothesis explaining aspects of typhoid fever pathogenesis. Infect. Immun. 74: 19-27.

Romling U., Bian Z., Hammar M., Sierralta W.D. \& Normark S. 1998. Curli fibers are highly conserved between Salmonella typhimurium and Escherichia coli with respect to operon structure and regulation. J. Bacteriol. 180: 722-731.

Simon R., Priefer U. \& Puhler A. 1983. A broad host range mobilization system for in vivo genetic engineering: transposon mutagenesis in Gram-negative bacteria. Bio/Technology 1: 784-791.

Stojilkovic I., Baumler A.J. \& Heffron F. 1995. Ethanolamine utilization in Salmonella typhimurium: nucleotide sequence, protein expression, and mutational analysis of the cchA cchB eutE eutJ eutG eutH gene cluster. J. Bacteriol. 177: 13571366.

Stolpe H., Grund S. \& Schroder W. 1994. Purification and partial characterization of type 3 fimbriae from Salmonella typhimurium var. copenhagen. Zentralbl. Bakteriol. 281: 8-15.

Tükel Ç., Akçelik M., de Jong M.F., Şimşek Ö., Tsolis R.M. \& Baumler A.J. 2007. MarT activates expression of the MisL autotransporter protein of Salmonella enterica Serotype Typhimurium. J. Bacteriol. 189: 3922-3926.

Tükel Ç., Raffatellu M., Chessa D., Wilson R.P., Akçelik M. \& Baumler A.J. 2006. Neutrophil influx during non-typhoidal salmonellosis: who is in the driver's seat? FEMS Immunol. Med. Microbiol. 46: 320-329.

Tükel Ç., Raffatellu M., Humphries A.D., Wilson R.P., AndrewsPolymenis H.L., Gull T., Figueiredo J.F., Wong M.H., Michelsen K.S., Akçelik M., Adams L.G. \& Baumler A.J. 2005. CsgA is a pathogen-associated molecular pattern of Salmonella enterica serotype Typhimurium that is recognized by Toll-like receptor 2. Mol. Microbiol. 58: 289-304.

Weening E.H., Barker J.D., Laarakker M.C., Humphries A.D., Tsolis R.M \& Baumler A.J. 2005. The Salmonella enterica serotype Typhimurium $l p f, b c f$, stb, stc, std, and sth fimbrial operons are required for intestinal persistence in mice. Infect. Immun. 73: 3358-3366.

Received January 9, 2009 Accepted April 21, 2009 